\title{
OPCIONES Y PREFERENCIAS LINGÜÍSTICAS DEL REY PEDRO IV DE ARAGÓN
}

\author{
FERNANDO GONZÁLEZ OLLÉ \\ Universidad de Navarra
}

1. La peripecia personal y la política, tan oscilantes y entrelazadas, de Pedro IV de Aragón ${ }^{1}$, requieren ser sabidas a la hora de examinar o explicar algunas de sus decisiones idiomáticas, pues su clave bien puede esconderse bajo avatares vitales. Aun antes de analizar particularmente tales decisiones, pronto permiten presuponerlas en sus líneas generales al ir conociendo la cambiante vinculación o preferencia del monarca hacia una u otra de las diferenciadas entidades territoriales componentes de la Corona aragonesa. Por todo lo dicho, mi primera tarea consistirá en proporcionar una imagen esencial, muy simplificada, del rey y de su reinado.

2. El futuro Pedro IV nació en Balaguer el año 1319, hijo primogénito de Alfonso IV de Aragón y Teresa de Entenza, heredera del condado de Urgel, que acabó, por este matrimonio, incorporado a Aragón. Al morir la reina, 1328, el rey contrajo nuevo matrimonio al año siguiente con Leonor, hermana de Alfonso XI de Castilla. La desmesurada ambición que, con los años, manifestó la nueva reina por dotar a sus hijos de una sólida posición en detrimento del infante Pedro, el primogénito real, y con abierta hostilidad hacia él, logró arrancar poco a poco del débil carácter de Alfonso IV importantes posesiones territoriales para los infantes Fernando y Juan: la ciudad de Tortosa, erigida en marquesado, Alicante, Orihuela, Játiva, Castellón, entre otras plazas. El propósito de Leonor era que el Reino de Valencia acabase separado del Reino de Aragón. La indignación de aragoneses y valencianos fue grande, algunos nobles y villas llegaron a enfrentarse al rey. Pero Leonor continuó sus manejos y mer-

${ }^{1}$ Adviértase, para evitar errores en las menciones de este rey y, especialmente, en las referencias bibliográficas, que algunos historiadores, de acuerdo con el punto de vista historiográfico adoptado o siguiendo sus preferencias personales, lo designan como Pedro III (de Cataluña), Pedro II (de Valencia) o Pedro I (de Mallorca). 
ced a varios infundios logró que fuesen ejecutados algunos consejeros reales y otros personajes que denunciaban sus maquinaciones y velaban por el infante Pedro, jurado sucesor en las Cortes zaragozanas de 1325. Éste, para verse con su padre, había de hacerlo a escondidas de su madrastra.

El temor de ser envenenado por ella le obligó a que con su hermano Jaime y un reducido grupo de caballeros fieles abandonara Zaragoza para refugiarse en la frontera de Francia, dispuesto a traspasarla en cualquier momento de peligro. Según él mismo referirá ${ }^{2}$ muchos años después, primero hubo de residir en Ejea (así consta documentalmente en varias fechas de 1330 y 1331) y luego en les muntanyes de Jaca, lugar del que, pasado el tiempo, guardará, por lo menos, un grato recuerdo gastronómico (cf. § 14).

3. Debido a enfermedad de Alfonso IV, el infante Pedro empezó a actuar como lugarteniente del reino. En circunstancias políticas adversas, contó con el principal apoyo de Pedro López de Luna y Ximénez de Urrea, obispo de Zaragoza $^{3}$, encargado, junto con otros nobles, por el rey de la educación del sucesor. En torno a éste se fue formando un partido aragonesista, ya fuerte cuando Alfonso IV muere en 1336. Dos meses antes, la reina Leonor, objeto de general aborrecimiento en Aragón, había huido, temerosa, a Castilla. Ahora son otros los enfrentamientos que amenazan al joven soberano.

Un hijo de Jaime II, por tanto tío de Pedro IV, el infante Pedro ${ }^{4}$, conde de Ribagorza y Ampurias, lugarteniente de Valencia de 1322 a 1324, con aspiraciones a la Corona aragonesa, tardó un año en reconocer la proclamación real, antes citada, de 1325 y se mostraba partidario de la reina Leonor y de sus hijos, a la vez que disgustado por la educación, entre aragoneses, recibida por el monarca, al juzgarla opuesta a los intereses catalanes. Dicho infante Pedro de Ribagorza y su hermano el infante Ramón Berenguer, conde de Prades, procuraron siempre desviar aquella orientación, hasta el punto de dirigir al rey, su sobrino, con aquiescencia de numerosas autoridades civiles y eclesiásticas, unas largas instrucciones escritas, según luego precisaré, con claros visos de exigencia, para insistir sobre cuanto previamente le venían aconsejando de palabra. En ellas le advertían de los peligros que, por su juventud e inexperiencia, corría el reino; de cómo había de disponer el régimen de su persona y casa; de la nece-

${ }^{2}$ Pere el Ceremoniós, Crònica, en Les quatre grans Cròniques, ed. de F. Soldevila, Barcelona, Selecta, $1983^{2}$, pág. $1021 b$.

${ }^{3}$ Desde 1314; arzobispo, tras la elevación de la sede, 1318, hasta su muerte, 1345. Canciller del reino entre 1336-1338 y, quizá, según luego indicaré, entre 1339-1345.

${ }^{4}$ Hacia 1305-1381. Hábil político, con inclinaciones culturales, autor de algunas obras didácticas y poéticas, participante en polémicas teológicas, reunía oportunas cualidades personales para ejercer ascendiente sobre su sobrino. 
sidad de cambiar sus consejeros y elegir otros, cuyas cualidades predeterminan, entre los mejores de sus súbditos; de la oportunidad de contar siempre con dos de aquéllos a su lado, etc. De no aceptar estas peticiones, debía procederse a una convocatoria de Cortes.

El rechazo del rey a tales interesadas recomendaciones fue muy violento, como propio de su irascible carácter. Las recomendaciones propuestas - responderá el monarca - parecen haber sido formuladas más para difamación y división que motivadas por un legítimo celo. La tensión así creada venía a sumarse a un previo choque familiar, producido poco antes. Al morir Alfonso IV en Barcelona, su hijo se dispuso a acudir a Lérida para enterrarlo allí, en cumplimiento de la voluntad paterna, según se lo comunicó a sus tíos, residentes en aquella ciudad. Pero éstos se habían apresurado, fraudulentamente, a sepultarlo en ella, pese a conocer la citada disposición testamentaria.

4. La ceremonia de coronación de Pedro IV, 1336, supuso un nuevo y profundo desacuerdo con sus tíos, los infantes, quienes le aconsejaron que, como conde de Barcelona, antes acudiese a ella para jurar los Usatges. El rey se negó, con razón, atento a la práctica tradicional ${ }^{5}$, por lo cual los infantes, casi toda la nobleza catalana, síndicos y procuradores de ciudades y villas de Cataluña no acudieron al acto, celebrado en Zaragoza, según costumbre, mientras las Cortes de Aragón le aclamaban con entusiasmo allí, satisfechas con la legítima preferencia dada a su reino. Sólo tiempo después acudió Pedro IV a cumplir su obligación legal con el Principado de Cataluña, pero no a Barcelona, sino a Lérida. El descontento de los catalanes fue general y tuvo manifestaciones políticas graves, como el rechazo de nombramientos para cargos públicos en algunas ciudades, con el alegato de que no procedían de su señor, el conde de Barcelona, sino del rey de Aragón. Algo similar ocurrió en Valencia, al quedar más postergado aún este reino.

Las maquinaciones del infante Pedro de Ribagorza y de la reina Leonor a favor de los hijos de ésta continuaron hasta lograr que el arzobispo de Zaragoza y canciller real, el antes citado Pedro López de Luna, principal valedor de Pedro IV, fuera llamado a la corte pontificia en 1338, para que informase, como imputado, sobre su postura en el conflicto entre el rey y su madrastra, con la acusación de que esa situación amenazaba la paz entre Aragón y Castilla. A la vez, alegaron, con éxito, la vejez de aquel eclesiástico para impedirle que ocu-

${ }^{5}$ En 1345, desde Perpiñán, escribía Pedro IV al Papa: La esgleya de Saragoça [...] és cap de nostre regne et en la qual tots nostres predesseçors e nós havem presa corona de nostra reyal dignitat. Pere III, Epistolari, ed. de R. Gubern, Barcelona, Barcino, 1955, vol. I (único publ.), pág. 98. Esta obra sólo recoge cartas compuestas en catalán y alguna, duplicada, en aragonés. 
pase cargos públicos. De este modo el infante Pedro de Ribagorza alejó temporalmente de Zaragoza el principal obstáculo para sus planes políticos. En ese momento, haciendo caso omiso de su provocativa retirada cortesana con motivo de la coronación, se acerca de nuevo a Pedro IV, se reconcilia con él y, como principal prohombre de la Corona, consigue ocupar la cancillería real ${ }^{6}, 1338$, desde la cual ejerce un decisivo ascendiente sobre el rey para inclinar pronto su interés político hacia Cataluña, en menoscabo de la orientación recibida de sus consejeros aragoneses.

Por propia y sorprendente voluntad, el nuevo canciller renunció al desempeño de su alto cargo tras un solo año de permanencia en él, para cumplir el propósito de entrar en Religión (si bien no lo haría hasta 1358, después de una importante actividad pública en la corte pontificia). Así y todo, parece indudable — según he anticipado- que durante aquel tiempo se iniciase el cambio de orientación política de Pedro IV. Hasta entonces su tendencia había sido continentalista, en calificación de Reglá ${ }^{7}$, pues los aragoneses nunca habían visto con agrado la política mediterránea de sus reyes, que satisfacía los intereses catalanes en detrimento de los suyos. La influencia del infante Pedro de Ribargorza, unida a otros sucesos que enseguida mencionaré, fue decisiva para acabar convirtiendo a Pedro IV en un monarca catalán, según extendida aceptación ${ }^{8}$. Entre tanto, el papa Clemente VI había revocado todas las prohibiciones sobre el arzobispo Pedro López de Luna, con el reconocimiento de que las delaciones provenían de sus enemigos. Tras esta resolución, fue repuesto en todos sus cargos ${ }^{9}$ hasta el fin de sus días, en 1345.

5. Al morir en 1347, sin dejar descendencia masculina, la reina María de Navarra, con quien Pedro IV había contraído matrimonio en 1338, el rey propone como sucesora de la Corona a su hija Constanza. Aunque aprobada la designación por una junta de juristas, al ser contrario a la tradición aragonesa el

${ }^{6}$ Fue el único canciller laico de la Corona.

7 J. Reglá Campistol, «La Corona de Aragón», en R. Menéndez Pidal, Historia de España, vol. XIV, Madrid, Espasa-Calpe, 1966, pág. 444.

8 Aunque muchos años después y en unas Cortes de Cataluña, celebradas en Tarragona, 1370, Pedro IV declarará (Parlaments a las Corts catalanes, Ed. de R. Albert y J. Gassiot, Barcelona, Barcino, 1928, pág. 46): Nostres predecessors [...], de comtes de Barcinona que eren, hagren lo regne d'Aragó per matrimonis, que incurre en intencionada (?) contradicción con su profesión de fe aragonesista, 1345, copiada en $\S 4$, pues en esta ocasión le importaba mucho, siempre astuto, presentarse como rey, no como conde, sin establecer distingos genealógicos.

9 Observo en este punto opiniones discrepantes, no contrastadas, entre los historiadores del reinado. Hay quienes afirman que al dejar el infante Pedro la cancillería, la ocupó Hugo de Fenollet, canónigo de Elna y luego obispo de Vic y de Valencia. En cualquier caso, consta que fue canciller. De este modo se continúa, para el cargo, con la remota tradición de prelados de procedencia levantina. 
que recayese en mujer, renacen con este motivo las revolucionarias Uniones de Aragón y de Valencia, encabezadas por el propio hermano del rey, Jaime, conde de Urgel, y por sus hermanastros, los infantes Fernando y Juan ${ }^{10}$, con notable número de nobles y procuradores de importantes ciudades y villas ${ }^{11}$. Con la imputación de que el rey ha cometido desafuero en su propuesta sucesoria, le obligan a celebrar Cortes en Monzón aquel mismo año. Pedro IV se ve forzado a ceder prácticamente a todas las pretensiones de los rebeldes: confirmó el Privilegio general (otorgado por Pedro III en 1283) y el Privilegio de la Unión (otorgado por Alfonso III en 1288), incluso hubo de sustituir personal de su casa por unionistas. Con el pretexto del desembarco de los benimerines, enseguida huye ocultamente a Cataluña con unos pocos fieles. Al divisar el territorio catalán, exclama, según él mismo indica en su Crónica $^{12}$ :

Bernat de Cabrera nos dix:

-Senyor, veets aquell lloc?

Et nós li diguem:

-Hoc.

-Doncs de Catalunya és.

-O terra beneita, poblada de llealtat! Beneit sia nostre senyor Deus, que ens ha lleixat eixir de la terra rebel e malvada! Maleit sia qui hi mir mal, car així mateix era poblada de lleials persones! Mas, bé havem fe en nostre senyor Déu, que la tornarem a son estament e punirem aquells qui hi miren mal.

Con la inestimable ayuda del recién citado Bernardo de Cabrera ${ }^{13}$, noble opuesto a las Uniones, que logra atraer para la causa real a destacados unionistas aragoneses, entre ellos a Lope de Luna, el principal noble aragonés, Pedro IV rehace en Barcelona sus efectivos, contando con la nobleza catalana, que siempre le fue fiel. Después se enfrenta bélicamente varias veces, con diversa fortuna, a sus adversarios, recibe en Valencia graves vejaciones personales y pasa momentos muy peligrosos y humillantes hasta que los realistas, con ayuda de tropas castellanas, vencen a los unionistas aragoneses en Épila, 1348,

10 Como un obstáculo para la armonía entre Castilla y Aragón los presenta el reciente estudio de M. T. Ferrer Mayol, Entre la paz y la guerra. La Corona catalano-aragonesa y Castilla en la Baja Edad Media, Barcelona, CSIC, 2005, especialmente, págs. 331-347.

11 E. Sarasa Sánchez, «El enfrentamiento de Pedro el Ceremonioso con la aristocracia aragonesa. La guerra con la Unión y sus consecuencias», en Pere el Cerimoniòs i la seva época, Barcelona, CSIC, 1989, págs. 35-45.

12 Pere el Cerimoniós, Crònica, pág. $1100 b$.

13 Calatayud, 1298 - Zaragoza, 1364. Gozaba de toda la confianza de Pedro IV, quien le había nombrado mayordomo real. Partidario de la monarquía autoritaria postulada por los consejeros roselloneses (formados en el Derecho Romano), su influencia sobre el rey será decisiva durante diecisiete años. La privanza se prolongó hasta 1364, en que injustamente, según acabó reconociendo el propio monarca, fue ejecutado. 
y en Murviedro, el mismo año, a los valencianos. Tras severa represión en Valencia, la vuelta a Zaragoza, aún reticente su nobleza, acabó con un desquite sangriento. Enseguida reunió allí Cortes, en las cuales destruyó materialmente (sea cierto o no que lo hizo valiéndose de su propio puñal) muchos documentos garantes de concesiones favorables a la nobleza ${ }^{14}$. Por supuesto, abolió el Privilegio de la Unión, aunque, sorprendentemente, reconoció el Privilegio general. La natural tendencia autoritaria del rey encontrará en adelante apoyo doctrinal en sus antes mencionados consejeros del Rosellón.

Un año después, 1349, tras breve vida de su segunda esposa, contrajo matrimonio con Leonor de Sicilia. Con el nacimiento de los infantes Juan y Martín, que en su momento regirían la Corona aragonesa, quedó superado el debatido y lamentable problema suscitado por la cuestión sucesoria. Las vinculaciones familiares, que enseguida menciono, de la nueva esposa supusieron una nueva e importante influencia en la orientación mediterránea de Pedro IV.

$\mathrm{Su}$ reinado es rico en otros acontecimientos políticos, todos de larga de duración, que no pueden omitirse para su cabal comprensión, aunque he de exponerlos de modo muy conciso por sus escasas repercusiones lingüísticas.

Del Reino de Mallorca, que comprendía las Baleares, el Rosellón, la Cerdaña y el señorío de Montpellier, se apoderó Pedro IV, tras varios intentos, al vencer en Lluchmajor, 1349, a Jaime III.

Cerdeña, conquistada por Alfonso II, se sublevó en 1347. Después de algunas batallas, con variables resultados, frente a los genoveses y junto a los venecianos, el propio Pedro IV desembarcó victoriosamente en la isla, 1354, y expulsó a buena parte de los habitantes urbanos; por último, sólo retuvo Alguer, repoblado con aragoneses y catalanes, y Cáller.

Poco antes he mencionado el tercer matrimonio del rey, con Leonor, hermana de Federico IV de Sicilia. Añádase que concertó también el de su hija Constanza con el propio rey siciliano. Pedro IV pretendía así la reintegración de la isla, conquistada por Alfonso IV, a la Corona aragonesa. Al morir Federico IV, sin descendencia masculina, Pedro IV se proclamó rey de Sicilia, 1377, y así obtuvo también los ducados de Atenas y Neopatria. Culmina entonces el imperio mediterráneo de Aragón.

Hasta aquí las grandes líneas de la política mediterránea, a las que debe añadirse, en cuanto a acción exterior, una ordinaria enemistad hacia Francia y, con más manifiesta persistencia, hacia Castilla. Aunque Pedro IV contribuyó presencialmente, junto con Alfonso XI, a la conquista de Algeciras, 1344, con su sucesor, Pedro I, sostuvo un larga guerra, 1356-1369, pródiga en resultados

\footnotetext{
${ }^{14}$ Esta acción tiene unas peculiares consecuencias secundarias, pues a ella se atribuye un notable vacío documental en los archivos medievales aragoneses.
} 
adversos para Aragón ${ }^{15}$, por la posesión de amplios territorios de Alicante y Murcia, entre otros litigios, como el puerto de Cartagena. En distintas ocasiones la flota del rey castellano atacó Barcelona y Valencia, mientras que por tierra sus tropas llegaron hasta las puertas de Zaragoza, tras tomar Calatayud y Tarazona, y penetraron en tierras levantinas. Aunque partidario de los Trastámaras, de quienes recibió ayuda y se la prestó, la llegada de éstos al trono castellano con Enrique II no aportó en general beneficios para Pedro IV. El nuevo rey de Castilla retuvo definitivamente las disputadas zonas levantinas y el tratado de Almazán, 1375, supuso el fracaso del proyecto, tan anhelado por Pedro IV, de conseguir la hegemonía aragonesa en la Península.

6. Muy discutida, desde sus contemporáneos hasta los historiadores modernos, la gestión política de Pedro IV, existe, por el contrario una amplia coincidencia sobre su personalidad. De complexión débil, fue enérgico de carácter, osado hasta la temeridad en enfrentamientos personales, violento, cruel, falaz. A la vez, adicto a la suntuosidad en su persona y a la solemnidad en el aparato de su corte, de acuerdo con una estudiada reglamentación establecida por él. Ambicioso en sus concepciones y realizaciones de gobierno ${ }^{16}$, según queda expuesto, no tuvo nunca reparos morales para lograr sus fines..

No deja de sorprender que idéntico empeño pusiera en la dedicación intelectual ${ }^{17}$, servida por una notable inteligencia. Amante de los libros, por cuya adquisición siempre estuvo interesado, formó una nutrida biblioteca. Fue también autor, cuando menos principal, de su Crònica. Asimismo compuso algunas poesías y piezas oratorias muy elaboradas. Impulsó la composición del máximo exponente de la historiografía medieval aragonesa, la Crónica de San Juan de la Peña (hacia 1370 se data el original latino, pronto vertido al aragonés y al catalán), como igualmente de traducciones de obras sobre variadas materias en distintas lenguas.

Esta misma actitud exhibe Pedro IV, de modo regular, en los aspectos formales y administrativos de gobierno, atento a la composición, reglamentada en

15 Que asimismo ocasionó un considerable decaimiento de la actividad intelectual de Pedro IV.

16 Sin oportunidad aquí para comentar la magnificencia de sus empresas artísticas, debo recordar algunas a fin de mejor presentar su personalidad. A Pedro IV se deben el Tinell, el Salón de Cientos y las Atarazas, de Barcelona; la catedral de Gerona; los mausoleos reales de Poblet; el Miquelet y la Lonja, de Valencia, etc., obras cuya construcción seguía de cerca. Relevante es también su conocida admiración por la Acrópolis ateniense; en su opinión, la más valiosa joya del mundo.

17 A la amplia bibliografía sobre los aspectos culturales del reinado, añádase la densa y ajustada exposición de J. M. Enguita y V. Lagüéns, en A. San Vicente, ed., Edición y estudios del «Ceremonial de consagración y coronación de los reyes de Aragón», Zaragoza, Institución Fernando el Católico, 1992. 
sus Ordinacions (obra a la cual de inmediato me referiré), de los documentos emitidos por su cancillería, a la cual acudía personalmente para intervenir en la redacción, a veces dictando palabra por palabra o retocando el texto tras una primera lectura, incluso interviniendo en su elaboración gráfica ${ }^{18}$, cuando se trataba de asuntos importantes. Según indica Gimeno Blay ${ }^{19}$, Pedro IV «introdujo la novedad de firmar de manera autógrafa los documentos de Cancillería». $\mathrm{Su}$ escritura «se revela como la de un calígrafo profesional», que se prodigó en esta tarea, hasta el punto de haberse conservado «un conjunto importante de autógrafos reales, sin parangón con sus antecesores». De su puño y letra suelen ser las cartas familiares.

7. Pedro IV reglamentó el servicio protocolario y burocrático del completo entorno palaciego mediante unas Ordinacions de la casa i cort (título abreviado. por el que suelen conocerse), datadas en 1344. Corresponden, básicamente, a la traducción literal al catalán de las Leges Palatinae Regni Maioricarum, 1337, realizada por Mateu Adrià, ampliamente modificada por las enmiendas, adiciones y glosas marginales autógrafas del propio monarca aragonés, según sus personales criterios. Probablemente, esta tarea la prosiguió de modo discontinuo «hasta el final de sus días» ${ }^{20}$, pues sentía la necesidad, casi obsesiva, de tener bien ordenada su corte y reinos, hasta extremos insignificantes, tanto por eficacia administrativa como por la necesidad de legitimar la posesión de algunos territorios ${ }^{21}$. Según su costumbre de consignar por escrito cualquier experiencia, a su inmediata disposición contaba siempre con dos secretarios, llegando al punto de que, según regulan las Ordinacions, uno debía pernoctar cerca de las estancias privadas del monarca. Pedro IV creó el archivo real con los documentos ordenados cronológicamente para facilitar su consulta, como tenía por sistema hacer. Para él, el conocimiento de la historia constituía un eficaz recurso a la hora de tomar de decisiones.

18 «Celoso del poder que encerraba la comunicación escrita, estuvo presente en la Cancillería cuando se tramitaban asuntos graves; en estas ocasiones fiscalizó completamente todos y cada uno de los momentos claves de la génesis documental. Llegó incluso a sustraer a la escribanía el despacho de algunos asuntos de gran importancia, tales como el pacto de ayuda suscrito con Enrique de Trastámara el año 1363. Tal vez para evitar la publicidad y notoriedad de las condiciones que imponían cada una de las partes, Pedro IV decidió escribirlo de manera autógrafa, sin necesidad de que interviniese escribano o secretario alguno». F. M. Gimeno Blay, Escribir, reinar. La experiencia gráfico-textual de Pedro IV el Ceremonioso (1336-1387), Madrid, Abada, 2006, pág. 22.

19 Íd., pág. 19.

20 Íd., pág. 79.

21 B. Palacios Martín, «Sobre la redacción y difusión de las Ordinacions de Pedro IV de Aragón y sus códices», $A E M, 1995$, vol. 25, págs. 659-681. 
Un intento de traducir las Partidas de Alfonso X al catalán no llegó a consumarse, al menos en su totalidad. Pedro IV poseía tres libres lenguatge castella formada, entregados, con el encargo de traducción, a Mateu Adrià, pero éste murió antes de terminar su labor. Al ordenar que se reclame a la familia del protonotario su devolución, Pedro IV revela su propósitos íntimos: Per tal que aquells fes tresladar en nostre lenguatge e fessem ordenar semblants leys, les quales poguessem esser dites nostres. Bien convenía el texto legislativo alfonsino para satisfacer aspiraciones e ideales políticos de Pedro IV tales como el establecimiento de normas para fortalecer el poder real ${ }^{22}$. Claro que llevado del hondo sentido de su personal realeza, desea además que se formulen literalmente en su propia lengua (cf. § 26), al igual que las Ordinacions.

Una aplicación práctica encierra asimismo el referido Ceremonial de consagración y coronación de los reyes de Aragón, cuya confección ordenó Pedro IV en 1353. Se ha conservado en versión latina, aragonesa (con presencia de rasgos catalanes y algunos, menos, castellanos) y catalana. El texto ${ }^{23}$ viene a confirmar el profundo gusto del monarca por las ceremonias, pues las acrecienta y exorna respecto a las consignadas en el ritual utilizado para su propia coronación el año 1336.

8. Por bien conocido y ya apuntado aquí, no me ocupo de su afán en adquirir obras de las más variadas materias o en disponer su traducción. Menos se ha atendido a su preocupación por dotar a la cancillería de obras de inmediata utilidad para su labor ordinaria, como se refleja en una orden de pago, 1357, por el diccionario latino de Iohannis Balbi ${ }^{24}$.

${ }^{22}$ No he encontrado datos precisos sobre la suerte corrida por las versiones aragonesas. Parece que se conserva un manuscrito con el comienzo de la Partida primera y varios, también parciales, de la segunda. Sabido su contenido, sirve para confirmar la presumible preferencia de Pedro IV hacia ésta.

23 No he acertado a averiguar con seguridad la lengua del texto original. Dada la predilección de Pedro IV por el catalán, como queda amplia constancia en el presente estudio, más el precedente de las Ordinacions, en cuya línea ordenancista se sitúa, puede suponerse con cierta lógica que también se hubiese redactado en aquella lengua. Ahora bien, el hecho de que la coronación de los reyes se acostumbrase a celebrar en Zaragoza (cf. § 4), me inclina decididamente a atribuirla al aragonés. A esta lengua corresponde la reciente edición poco antes citada; sólo para algunas oraciones y bendiciones se incorpora el latín. Remito de nuevo al estudio de Enguita y Lagüéns. Según B. Palacios Martín, La Coronación de los Reyes de Aragón (1204-1410). Aportación al estudio de las estructuras medievales, Valencia, Anubar, 1975, el Ceremonial se compuso en latín, 1353, con traducciones para Aragón, Cataluña y Valencia. En otro estudio, ya citado, del mismo autor, Sobre la redacción..., el Ceremonial se añadió, 1553, a las Ordinacions, pero antes, 1336, se había elaborado una redacción aragonesa para la inmediata coronación del monarca.

${ }^{24}$ Apud J. Trench y A. Canellas, «La cultura dels escribes i notaris de la Corona d'Aragó, 1344-1479», Caplletra, 1988, vol. 5, págs. 1-42; pág. 14. 
Quendam librum vocatum Catholicon ad opus erudicionis scriptorum nostrorum et aliorum de nostra scribania, ad hoc, ut en ipso libro, per eosdem vocabulorum copia habeatur. Volumus tamen quod dicto Prothonotario et deinceps sibi successoribus in officio antedicto faciatis de dicto libro ad eternam rei memoriam notamentum in libris notamentorum vobis comissi officii, ut idem liber est eidem scribanie perpetuo conservetur.

Claro está que sería un error tomar dicha obra como un mero libro auxiliar. Esta y otras serán los instrumentos para la mejora del latín cancilleresco, iniciada durante este reinado, siguiendo las pautas del Ars dictandi, de acuerdo con las recomendaciones de las Ordinacions. En esta obra, Mateu Adrià ya se inspira en la sintaxis y en el vocabulario latinos para ilustrar el catalán, según se desprende de algunas cartas reales. En torno a 1380 la cancillería ha adoptado el nuevo estilo, un proceso que culminará en el siglo $\mathrm{xv}$ e influirá en toda la prosa catalana. Asunto este ajeno a la finalidad del presente estudio, pero resultaría improcedente silenciarlo aquí.

Las mencionadas Ordinacions prescriben también que se recojan por escrito todos los actos de gobierno para puntual recuerdo de su memoria. La frecuente utilización de las piezas conservadas en el archivo, cuya finalidad, como dejo indicado, se orienta a la toma de nuevas decisiones políticas, queda repetidamente atestiguada por notificaciones en que reclama a aquél el envío de determinados fondos. Tal manera de proceder se refleja, por ejemplo, en esta anotación autógrafa de Pedro IV a su Crònica, donde certifica: Aquesta Crònica és comprovada ab cartes públiques del nostre archiu et és vera.

9. Al ascender Pedro IV al trono de Aragón, la situación lingüística del Reino dentro de la Corona puede delinearse en estos términos ${ }^{25}$. El aragonés era su lengua propia y la de uso más extendido, según queda patente a la vista de numerosas colecciones documentales, muchas de ellas, publicadas. Desde edictos de la Casa Real hasta cartas de compraventa suscritas en una modesta escribanía rural, pasando por toda clase de emisores y de materias, la lengua romance por excelencia, en la práctica oral y en la escrita (excluyo, obviamente, en cuanto a ésta el latín), es el aragonés. Quizá pueda parecer obvia esta información, pero convenía dejarla asentada, a la vista del relieve que se suele conferir, ciertamente con razón, a la presencia y empleo del catalán en la cancillería regia, según habrá ocasión de continuar observando.

La entronización de la Casa condal barcelonesa, con el advenimiento de Ramón Berenguer IV en 1137, ocasionó, durante siglos, la orientación política

25 Para una detenida exposición, cf. F. González Ollé, «Actitudes linguiísticas de los Reyes de Aragón» (de próxima publicación). 
de Aragón hacia Cataluña y, con ella, la utilización mayoritaria, pero no exclusiva, de la lengua catalana, cuando cedió la latina, en la documentación procedente de la cancillería real y, probablemente, dentro del círculo familiar y cortesano de los monarcas. A la evidente prueba documental ha de añadirse que los cancilleres, cuando no consta expresamente, a juzgar por sus nombres y por sus cargos previos, revelan su naturaleza catalana o valenciana, al igual que muchos de sus subordinados. Aún queda por señalar un indicio más claro de la catalanización idiomática de la cancillería. Un estudio de Sevillano Colom ${ }^{26}$ recoge numerosas indicaciones sobre el régimen interno de dicho organismo: formularios, prescripciones, organización laboral, etc. Todas figuran redactadas en lengua catalana.

La profusión de textos catalanes y, por lo general, su elevado rango legal, aunque sólo fuera por el natural ascendiente público y el respeto al organismo emisor, etc., contribuirían sin duda al prestigio que debía de conocer el catalán en cuanto lengua de dicha documentación. Pero estas manifestaciones de la lengua escrita bien podían estar contrapesadas, aun sin tener en cuenta el empleo de la general y propia en Aragón, por otros medios favorables a ella en las manifestaciones de la lengua habitual. Pienso en el desarrollo oral de sesiones de cortes (volveré luego sobre ellas para importantes precisiones) y de sus respectivas actas, con la obligada incorporación de sus acuerdos, previa traducción latina, a los Fueros de Aragón, que los monarcas estaban obligados a jurar durante la ceremonia de su coronación. En aragonés se redactaron también los textos del Privilegio general (1283) y del Privilegio de la Unión (1287): con ellos, los aragoneses muestran de modo patente el alcance generalizado de su lengua propia, en varias ocasiones (entre otras, los enfrentamientos con Pedro IV) para reclamar derechos ante los reyes.

10. En su examen monográfico de la cancillería de Pedro IV el antes mencionado Sevillano Colom ${ }^{27}$ presta atención, desde un punto de vista diplomático, a la lengua empleada en su tarea documental. De modo escueto, suficiente para su propósito, desvela esta distribución: latín, para los privilegios solemnes, concesión de títulos, fueros; aragonés y catalán, para las disposiciones administrativas. En cuanto a la correspondencia emanada hacia el exterior, la variedad es considerable: para Castilla y Portugal, latín y «castellano (mejor sería decir en aragonés)»; para Navarra, Francia, Italia, Inglaterra y Chipre, la-

${ }^{26}$ F. Sevillano Colom, «De la cancillería de la Corona de Aragón», en Martínez Ferrando, archivero. Miscelánea de estudios dedicados a su memoria, Barcelona, Anabad, 1968, págs. 451-480.

27 F. Sevillano Colom, «La cancillería de Pedro IV el Ceremonioso», AHDE, 1950, vol. 20, págs. 137-241. 
tín; para Armenia y Babilonia, catalán. Me propongo precisar de modo sustancial esta información, y aun enmendar algunos aspectos, especialmente para la alternativa de aragonés y catalán.

Mi personal examen de casi un millar de documentos de Pedro IV me autoriza a señalar cómo se produjo un temprano y radical cambio en su preferencia idiomática inicial. Innovación sostenida con constancia, que, sin embargo, no supone exclusividad. Antes bien, como asimismo confío haber descubierto, a lo largo de su reinado abandona ocasionalmente su lengua preferida a favor de otras, en función de determinados criterios que iré exponiendo.

11. Para sus primeros testimonios escritos, el futuro rey se vale del aragonés. Difícilmente cabría suponer el uso de otra lengua, si se recuerda su largo y forzoso alejamiento de la corte zaragozana durante la infancia y, en consecuencia, su residencia más o menos encubierta, en el norte de Aragón, que limitaba sus oportunidades de trato oral a los pobladores de aquella zona y a una muy reducida proporción de la nobleza, cuya procedencia era aragonesa.

De esta época se conserva una copiosa serie de documentos ${ }^{28}$ relacionados con la vida ordinaria del infante Pedro, datados entre 1326 y 1335. Además de los abundantes en latín, cuya presencia va decayendo, el mayor número de la totalidad suscrito por el infante, hasta 51, está redactado en aragonés, por sólo dos en catalán. Sorprende una misiva de 1334 en que un secretario se dirige en latín al arzobispo de Zaragoza para trasmitirle un breve mensaje del infante, redactado en catalán. El aragonés es la lengua habitual, salvo muy pocos en latín, en las muchas cartas dirigidas a su padre, Alfonso IV, desde el primer año de ausencia, pero también a otros destinatarios, por lo general funcionarios locales. Para éstos también utiliza a veces el latín, con contenido idéntico a otros documentos escritos en aragonés. El catalán, salvo los dos documentos antes indicados, corresponde a un buen número de recibos contables, justificantes económicos, concesiones, etc., que firman diversos funcionarios de su entorno, atenidos, sin duda, a la habitual práctica reglamentaria, antes mencionada, de la cancillería.

También resultan muy reveladores del inicial talante idiomático de $\mathrm{Pe}$ dro IV unos documentos ${ }^{29}$ en que, siguiendo su arraigada costumbre de dejar por escrito constancia de sus actos, relata, en aragonés, lo sucedido con sus tíos tras el plante y exigentes requirimientos de éstos con motivo de la coronación real, según antes referí, basado precisamente en estos testimonios. Con data de

28 D. Girona i Llagostera, «Itinerari de l'infant Pere (desprès Rei Pere III)», EUC, 1933, vol. 18, págs. 336-356; 1934, vol. 19, págs. 80-262.

29 Publicados por J. Rius Serra, «L'Arquebisbe de Saragossa, canceller de Pere III», AST, 1938, vol. 8, págs. 1-62. 
17 de marzo de 1336 Pedro IV hace levantar acta de una reunión pública celebrada en su palacio, durante la cual da a conocer la actitud de los infantes catalanes mediante la lectura de una carta recibida de ellos. En el texto del acta incluye una copia literal de dicha carta, compuesta en catalán.

Dos días después el rey les responde con otra carta, también en aragonés, para trazar una breve reseña de las recientes relaciones con ellos, sus tíos, que fueron demandados e clamados por el dito senyor rey a su presencia. Les acusa de haberse ausentado de Zaragoza, con pretextos que él les había rebatido previamente, sin recibir debida satisfacción: No ayan dreitament ne plenera a el respondido ne consellado. Por eso les había enviado a su portero mayor para que cara a cara les leyese la citada carta.

Simplifico, por innecesaria aquí, la exposición completa de este episodio, que alberga otras incidencias. Sí resaltaré el dato lingüístico ya anticipado. El nuevo rey continúa usando la misma lengua de sus primeros escritos, el aragonés, bien sea por inercia o por espontánea convicción, bien sea por estudiada actitud para reforzar por este medio su personalidad mediante la diferenciación idiomática frente a sus contradictores (con la especial circunstancia, antes mencionada, de que Alfonso IV había designado a Ramón de Ribagorza como tutor de su hijo), que siempre manejan el catalán. El propósito atribuido a Pedro IV encuentra firme apoyo en su carácter, manifestado de modo similar en otras relevantes ocasiones de diversa índole ${ }^{30}$. Sin embargo, esta predilección va a durarle poco y hasta prácticamente llega a abandonar de modo definitivo el empleo del aragonés, según iré mostrando.

En la colección documental hasta aquí utilizada, la compuesta por Serra, que se ciñe a los años iniciales de su reinado, Pedro IV se vale del latín, no sólo en las cartas dirigidas a la Santa Sede, sino para asuntos de escasa entidad pública, como instrucciones prácticas dirigidas a sus agentes enviados a ella; asimismo, en otros documentos propios del gobierno interior de su Reino. Tal ocurre en notificaciones de julio y noviembre de 1338 cursadas al arzobispo de Zaragoza sobre el desempeño de la cancillería; en otra de septiembre del mismo año a su tío Ramón Berenguer para que no retrase un viaje; etc.

12. De los 354 documentos signados por Pedro IV desde el primer año de su reinado, 1336, hasta uno antes de su muerte, enero de 1387, que Rubió y

${ }^{30}$ Valga recordar una muy temprana. Según refiere el propio Pedro IV en su Crònica, durante la ceremonia de su coronación se anticipó, tras oportuna reflexión por su parte y sorpresa de los asistentes, a tomar del altar la corona regia, para evitar que se la impusiese el arzobispo de Zaragoza. De este modo impedía que nadie pudiera imputarle -insiste- cualquier género de subordinación. 
Lluch ${ }^{31}$ publicó en una copiosa y variada colección de fuentes históricas medievales, su distribución por lenguas es la siguiente: catalán, 177 documentos; latín, 163; aragonés, 14. Una división de los 50 años, largos, de su reinado en dos etapas de 25 años cada una (a la inicial corresponde un total de 144 piezas; a la última, de 210), invierte sensiblemente la proporción entre las dos lenguas mayoritarias: el catalán distribuye su total entre las 44 y 133 piezas de cada respectivo período; el latín entre 95 y 68. Éste reunía, pues, en el primer período más del doble que el catalán; mientras que en el segundo período el catalán dobla prácticamente al latín.

Expongo de modo esquemático los precedentes datos para facilitar su comprobación y su comprensión:

\begin{tabular}{|l|c|c|c|}
\hline & $1^{\text {a }}$ etapa & $2^{\text {a }}$ etapa & total \\
\hline latín & 95 & 68 & 163 \\
catalán & 44 & 133 & 177 \\
aragonés & 5 & 9 & 14 \\
\hline
\end{tabular}

Con todo, estimo poco relevante parte de la precedente distribución, aquella que no indica sino el crecimiento de una lengua vulgar en sustitución de latín, pues con toda probabilidad sucedió idéntico proceso en cualquier área romance contemporánea. Por el contrario, tras lo observado en la documentación inicial, antes analizada, de Pedro IV, el dato relevante, auténtica novedad, es la implantación del catalán, aunque primeramente éste tardó en prevalecer sobre el latín, como cabía esperar, en detrimento final del aragonés, con clara preferencia utilizado en sus años juveniles. Pero, a la vez, tampoco cabe propiamente hablar de sorpresa, conocida la práctica secular de la cancillería aragonesa, a cuyos hábitos profesionales habrá de atribuirse la final y decidida elección del catalán y el arrumbamiento del aragonés. Cambio que, sin duda, contó con la aquiescencia o el impulso del monarca, pues de otro modo, conocida su personalidad, no se hubiera producido.

Sin mengua de esta última información, importa investigar el dato de haberse mantenido el uso, aunque tan precario, por no decir irrelevante, del aragonés $^{32}$ frente al catalán. Empleado aquél desde el año inicial del reinado hasta

31 A. Rubió y Lluch, Documents per l'historia de la cultura catalana mig-eval, Barcelona, IEC, 1908-1921.

${ }^{32}$ Cuestión distinta, al parecer no estudiada, es que en los documentos catalanes se deslicen aragonesismos, y no de modo inconsciente, que resultaría fácilmente explicable, sino con plena 
el penúltimo, el hecho de haber pasado de 5 documentos en el primer período a 9 en el segundo, no permite hablar propiamente de crecimiento respecto a las otras dos lenguas, puesto que el número total de documentos examinados aumentó considerablemente, como acabo de consignar. El interés específico de tal conservación minoritaria reside en la causa o, mejor, diversidad de causas que parecen sostenerlo. Para descubrirlas, empezaré estableciendo una relación de todos los documentos aragoneses (varios contaminados de castellanismos) signados por el rey, con su data y destinatario:

- 1336, a su cambrero, Lop de Gurrea.

- 1339, a su hermana, la infanta María.

- 1351, a maestre Alfonso, dos.

- 1352, al merino de Zaragoza.

- 1360, a Johan Ximenes d'Osca, Justicia de Aragón.

- 1367, a la iglesia de Santa María de Meyavila, en Calatayud.

- 1370, a Juan Fernández de Heredia, gran maestre de Rodas, dos.

- 1371, a Juan de Barbastro.

- 1371, a Juan Fernández de Heredia, gran maestre de Rodas.

- 1372, íd.

- 1373, al monasterio de San Victoriano, en Navarra.

- 1386, a Juan Fernández de Heredia, gran maestre de Rodas.

A la vista de determinadas características, que enseguida enuncio, concurrentes en la identificación de los destinatarios, no me parece aventurado sostener que corresponden a sujetos más ligados, por diversidad de motivos, a Aragón que a Cataluña. Aunque para alguno de los citados emplee el catalán en otras cartas, infiero que Pedro IV procura acomodarse, sin exclusividad, a la lengua más idónea para cada receptor.

Se me ocurre que este modo de actuar bien puede responder en el Rey Ceremonioso a una actitud de deferencia hacia sus destinatarios, al menos en varias ocasiones. Desgrano algunas de las posibles motivaciones, reducibles a razones de un genérico aragonesismo, que podría suponerse a juzgar por variados indicios:

- La forma del nombre que reciben: Alfonso, Juan, según el criterio aplicado por Pedro IV a su Crònica, en la cual los nombres personales sue-

intención en algunas ocasiones. Tal es el caso, entre los recogidos por Gubern, Epistolari..., pág. 10n9, de: És ajornat o, segons Aragó, aplazat. Conocido el desvelo de Pedro IV por la precisión, a un motivo de claridad más que a cualquiera otra razón habrá de achacarse esta peculiar sinonimia. 
len adoptar la propia que revisten en la lengua de su portador ${ }^{33}$ (los personajes castellanos son llamados, por ejemplo, Alfonso, Jaime o Pedro, y no Anfós, Jacme o Pere, respectivamente, como ocurre con sus súbditos).

- Localización territorial: Osca, Calatayud, Barbastro (para este topónimo se renuncia además a la forma Barbastre, normal en catalán); el monasterio navarro de San Victoriano. Del citado Juan de Barbastro se sabe que tradujo, precisamente al aragonés, la Suma de historia del mon, libro al que enseguida me referiré.

- Personas de la familia real residentes en Zaragoza: su hermana María, cuya lengua usual sería probablemente el aragonés.

- Cargos públicos aragoneses: Merino de Zaragoza, Justicia de Aragón, Cambrero real.

- El caso más repetido y notable es el de Juan Fernández de Heredia, de cuya condición preferente de hablante aragonés no cabe dudar, conocida la lengua predilecta de sus traducciones. Parece lógico conjeturar que el rey, dada su fuerte inclinación cultural, no podía por menos de prestarle particular deferencia ${ }^{34}$. En las cartas de 1370, la segunda, 1371 y 1372, el aragonés resultaba especialmente apropiado, pues en aquella el rey le acusaba recibo del libro clamado Suma de las Istorias, en frances [...]. E nos, segund vos havemos prometido, fazemos las dita Suma d' Istorias transladar en aragonés; en las dos siguientes el rey le notificaba que el libro appellado Suma de las Istorias del Mundo vos havemos feyto traslatar de frances en aragones y comunicaba su envío, al tiempo que le anunciaba el translado en aragones de otro ${ }^{35}$.

En confirmación de la línea expuesta es oportuno añadir una noticia aislada. De una carta, 1348, dirigida a su tío el infante Pedro de Ribagorza, redactada en catalán, se conocen ejemplares iguales para otros nobles. Sin embargo, idéntica misiva, en cuanto al contenido, presenta texto aragonés en las copias desti-

${ }^{33}$ Si Leonor de Castilla, hija de Fernando IV el Emplazado, siempre es designada como Elionor, bien cabe atribuirlo a que por su matrimonio con Alfonso IV el Benigno se convirtió en reina de Aragón.

${ }^{34}$ En especial, si se sabe, a estos mismos efectos, que durante muchos años fue consejero real, siempre fiel en peligrosos enfrentamientos con la Unión aragonesa, encargado de arriesgadas misiones bélicas y delicadas gestiones diplomáticas, etc. Las cualidades intelectuales, políticas y militares del gran maestre del Temple le ganaron un profundo aprecio de Pedro IV. El monarca con frecuencia acudió a él, cuando cesó en su servicio permanente para dedicarse a asuntos de su Orden.

35 También en materia de libros, Juan I, desde sus años de infante, se comunica en aragonés con Fernández de Heredia. 
nas a Pedro de Jérica y a Lope de Luna (éste, como antes dije, la figura más destacada de la nobleza aragonesa) ${ }^{36}$.

Claro está que el criterio expuesto puede asimismo responder a la precisión textual tan propia de Pedro IV. También en su Crònica encuentra apoyo esta suposición, pues en muchos pasajes los parlamentos de determinados personajes no catalanohablantes se presentan en su propia lengua, según luego ilustraré.

13. Analizo, para contrastar resultados, una amplia colección documental real, de vario contenido en este caso, la reunida por López de Meneses ${ }^{37}$. Está formada por 141 piezas, que van de 1336 a 1387. Su distribución por lenguas —repito la forma de presentación antes seguida - es la siguiente: catalán, 56 documentos; latín, 72; aragonés, 12; francés, 1. La misma división, antes practicada, de los 50 años, largos, de su reinado en dos etapas de 25 años cada una (a la inicial corresponde un total de 88 piezas; a la última, de 53), invierte sensiblemente la proporción entre las dos lenguas mayoritarias: el catalán distribuye su total entre las 16 y 40 piezas de cada respectivo período; el latín entre 64 y 8 . Éste reunía, pues, en el primer período el cuádruple que el catalán; mientras que en el segundo período el catalán quintuplica al latín. Estos resultados se muestran concordes con los obtenidos para la serie documental anterior y merecen idéntico comentario general, que, por tanto, no repetiré en cuanto a las sustituciones de uso idiomático, así confirmadas.

Sólo respecto al aragonés, en mínima paridad, no cabe concluir lo mismo. La nueva serie diplomática invierte la relación antes observada entre la primera y la segunda etapa. En conjunto, ha disminuido la aplicación textual de dicha lengua, si estadísticamente así cabe opinar, vista su precariedad, en cuanto a la presencia total; pero ha crecido la relativa, dado el menor número de documentos examinados.

Como antes, expongo de modo esquemático los precedentes datos para facilitar su comprobación y su comprensión:

36 Epistolari..., vol. I, pág. 98.

37 A. López de Meneses, «Florilegio documental del reinado de Pedro IV de Aragón», CHE, 1950, vol. 13, págs. 181-189. La serie sigue, con numerosas entregas, discontinuas, en números sucesivos de la misma revista. La última parece corresponder al año 1962, vol. 36, aunque en ésta, como en las anteriores, figura la indicación de continuará. Al final, existe alguna confusión en la numeración de las piezas, pero no parece afectar al total de ellas. Aunque al comienzo del florilegio se anuncia que la ordenación es cronológica, a partir del documento núm. 102 se reinicia dicho orden. 


\begin{tabular}{|l|c|c|c|}
\hline & $1^{\text {a }}$ etapa & $2^{\text {a }}$ etapa & total \\
\hline latín & 64 & 8 & 72 \\
catalán & 16 & 40 & 56 \\
aragonés & 7 & 5 & 12 \\
francés & 1 & 0 & 1 \\
\hline
\end{tabular}

Otra serie documental heterogénea ${ }^{38}$ contiene 52 piezas, 1336-1345, de Pedro IV, en latín, salvo dos en catalán y una que tanto pudiera corresponder al aragonés como al castellano. La presencia de esta carta, datada en 1340, supone la confirmación de uno de los criterios de elección idiomática antes propuestos, pues va dirigida a su tía María, viuda del infante Pedro de Castilla.

14. Las razones del crecimiento del catalán en detrimento del latín ya han quedado expuestas. Se percibe con claridad que para asuntos de cierto alcance legal (nombramientos, órdenes de detenciones o excarcelaciones, ejecución de obras públicas, concesión de títulos universitarios, licencias mercantiles, etc.), con independencia de la condición de los afectados, el latín cede el paso a su expresión en catalán. Las circunstancias antes alegadas a favor del empleo del aragonés (los correspondientes documentos se extienden desde 1341 a 1387) también ofrecen ahora validez, en términos generales, para explicar esta elección, pero dado el carácter particular con que antes las presenté, prefiero examinar asimismo los oportunos motivos de cada uno de los nuevos casos.

Quizá no a otro motivo, sino al recuerdo de los lugares donde trascurrió su infortunada infancia, quepa atribuir que en aragonés, su lengua usual de entonces, se dirija, desde Valencia, a Jaca (cf. § 2), muchos años después, 1349, para encargar perniles, manteca y quesos con que celebrar la Navidad. Otra carta va al concejo de Ejea, también su lugar de estancia juvenil. Con destino a Aragón sólo redacta en aragonés dos documentos más, destinados al baile de Daroca y a las aldeas de Calatayud.

Pedro IV escribe en aragonés a sus destinatarios del Reino castellano: a Alfonso XI de Castilla, por dos veces; a Juan I de Castilla; cerca ya de la muerte, a su nieto, Fernando de Antequera; a Blanca de Borbón, esposa de Pedro I de Castilla. Añádase Carlos II de Navarra. También, a miembros de su familia: a su tía abuela, Isabel de Aragón (Santa Isabel de Portugal); a su hija Leonor.

\footnotetext{
38 J. Rius y Serra, «Més documents sobre la cultura catalana medieval», EUC, 1928, vol. 13, págs. 135-170.
} 
15. La diversidad lingüística recién expuesta se observa asimismo en otro documento $^{39}$, ajeno a la colección recién examinada. Se trata de un acuerdo, 1363, autógrafo de Pedro IV, sobre ayuda mutua, con el conde Enrique de Trastámara, luego Enrique II de Castilla. Incluso la parte signada por éste figura en aragonés (así, por ejemplo, se lee: Segunt desuso ye por vos deto), sin que obste para suponer la existencia, en su momento, de un duplicado escrito únicamente en castellano.

En la treintena de cartas que Pedro IV envió al sultán de Babilonia ${ }^{40}$, el catalán es casi general, con algunas pocas misivas en latín, más otra en ambas lenguas.

16. El examen de las series documentales utilizadas que, unidas a otras piezas aisladas también vistas, sobrepasan ampliamente el medio millar de documentos, autoriza a sacar algunas conclusiones sobre los criterios directores de la actitud lingüística manifestada por Pedro IV. Pasados sus primeros años, en que el aragonés constituye la lengua principal de su documentación, el rey imprime un radical giro (prescindo, ahora, obviamente, del latín) en su acomodación idiomática para valerse casi en exclusiva del catalán. A mi entender, la sustitución está provocada por la interacción de motivos personales y políticos, genéricamente aludidos al comienzo del estudio.

La acogida por parte de Pedro IV, tras el rechazo inicial, al infante Pedro de Ribagorza, persistente partidario de la política mediterránea de la Corona, para el oficio de la cancillería real, jugaría sin duda un relevante papel en la aceptación, con renuncia a la continentalista, de aquella política. De ahí, la oportunidad, si no necesidad, de la adopción de la lengua catalana en el desempeño del gobierno. Para aplicar la innovación formal - en realidad, un retroceso- contaba de antemano con un idóneo instrumento bien experimentado: la cancillería real. En modo alguno, conocida la personalidad de Pedro IV, sería admisible pensar en una imposición de la cancillería, por grande que fuese el peso de ésta.

Por otra parte, de la libre elección lingüística del monarca ofrecen prueba irrefutable la redacción de su Crònica y las principales traducciones debidas a su iniciativa, para las cuales se presenta impensable admitir cualquier injerencia ajena.

El agradecimiento a la constante fidelidad de Cataluña al monarca, según refleja éste en su Crònica (cf. § 5), frente a las humillantes coacciones sufridas

\footnotetext{
39 Ed. de Gimeno, Escribir..., pág. 201.

40 A. López de Meneses, «Correspondencia de Pedro el Ceremonioso con la Soldanía de Babilonia», CHE, 1959, vol. 30, págs. 293-337.
} 
por él en Aragón a causa de los movimientos unionistas, hubo de despertar en Pedro IV sentimientos de afecto que sumar a las recién apuntadas razones de eficacia administrativa. Quizá existan otras causas para explicar la definitiva elección a favor del catalán, pero creo que no pueden excluirse las apuntadas.

El habitual comportamiento idiomático se quiebra en ocasiones, no necesariamente, a favor del aragonés en escritos dirigidos a personas o instituciones de Aragón. Idéntica elección se produce, pero en este supuesto de modo casi constante, en los documentos destinados a los territorios al oeste de Aragón, por lo general al rey de Castilla o a personas de la corte real castellana. Por cuanto se me alcanza, el empleo del aragonés presenta su manifestación más constante y regular, según he advertido, en la correspondencia con los monarcas castellanos y su entorno social.

Aunque para algunos destinatarios incursos en la adscripción recién citada emplee a veces el catalán, infiero que Pedro IV accede a acomodarse, sin exclusividad, repito, a la lengua más idónea para cada receptor. Cabe suponer que este criterio haya de atribuirse a una concesión, por cuanto que accede cortésmente a dirigirse a los castellanos en aragonés, consciente de que esta última lengua les resultaría de más fácil comprensión que el catalán.

Claro que en ese comportamiento idiomático no ha de descartarse un motivo de personal enaltecimiento, tan propio de su carácter, en una línea antes observada ( $(4)$ : mediante la lengua propia de un reino, Aragón, reafirmaba ante otros reyes que él también lo era. Mientras que el uso del catalán se prestaba a aparecer como solamente conde, de Barcelona.

Huelga advertir la ausencia de cualquier circunstancia objetiva para que Pedro IV usase el castellano. Antes al contrario, pues sus personales vivencias íntimas bien podían inclinarle a rechazarlo, dadas sus desfavorables experiencias con Castilla o, mejor, con castellanos: desde los padecimientos a que le sometió su madrastra, castellana, hasta los adversos resultados en las guerras que sostuvo con Pedro I de Castilla.

17. De muy distinta naturaleza que la documentación hasta ahora examinada, otra interesante fuente idónea para conocer la situación lingüística de la Corona son las actas de las sesiones de Cortes (generales o de cada territorio confederado), pero este recurso ofrece no pocas dificultades, que impiden realizar aquí un examen completo y pormenorizado ${ }^{41}$. En primer lugar, porque no se conserva toda la documentación pertinente y aun buena parte de la conserva-

${ }^{41}$ La bibliografía consignada a lo largo del presente estudio ofrece datos de interés para la mejor inteligencia de esta cuestión. 
da figura en copias divergentes ${ }^{42}$ o tardías o permanece inédita (noticias de esta procedencia, suministradas por historiadores, no suelen indicar la lengua de su fuente) ${ }^{43}$. Además, aunque existen testimonios suficientes para asegurar que las sesiones se desarrollaban en lengua vulgar, a veces su contenido sólo ha llegado en versión latina. Éste es el curso administrativo que solía darse de modo regular a los acuerdos emanados de cada reunión: estaba preceptuado que se tradujesen de romanz en latín antes de proceder a incorporarlos al libro de los Fueros de Aragón, para conferir valor legal a las resoluciones que afectaban particularmente a este reino. Constituyendo el libro dezeno, al que luego me referiré, de la compilación foral aragonesa, empiezan a incluirse los acuerdos tomados en las Cortes celebradas por Pedro IV. Éste no hace sino seguir la praxis iniciada por Jaime II, quien desde 1300 formó el libro noven de los citados Fueros con los acordados durante su reinado, previa traducción al latín encargada al Justicia de Aragón ${ }^{44}$.

18. En las cortes generales de Monzón, 1362-1363, figuran en latín ${ }^{45}$, con algún brevísimo párrafo en catalán, las varias convocatorias, la relación de procuradores llamados, la Preconizatio real, expuesta de modo conciso en estilo indirecto, como asimismo la respuesta del infante Fernando de Trastámara. Mediante escrito conjunto, compuesto exclusivamente en catalán y en estilo directo, intervienen, en nombre de toda la curia, los obispos de Lérida y Huesca junto al magistral de Monzón. Continúa la extensa narración de todo el desarrollo propiamente dicho, con algunas advertencias, propuestas, órdenes, etc., en redacción latina, interrumpida de vez en cuando por el catalán. Ésta será la lengua de toda Proposición real, como también la de largos acuerdos dirigidos a Aragón y a Valencia (no figura Cataluña, que previamente a las Cortes había

42 Del borrador original que resumía el desarrollo de una reunión de Cortes se sacaban textos más completos, en distintos momentos, para diversos destinatarios en función de los intereses de cada uno. De ahí las divergencias, variable extensión e información, etc. que pueden observarse en las copias conservadas. Cf. J. M. Lacarra, «Las Cortes de Aragón y de Navarra en el siglo XIV», AEM, 1970-1971, vol. 7, págs. 645-652. Enseguida quedará patente a propósito del caso concreto de las Cortes de 1362. Para una detallada exposición de la tarea burocrática en los procesos de trasmisión y conservación de esta documentación, cf. E. Sarasa Sánchez, Las Cortes de Aragón en la Edad Media, Zaragoza, Guara, 1979, especialmente págs. 117-121.

${ }^{43}$ La vieja serie, iniciada por la Real Academia de la Historia, sobre Cortes de los antiguos Reinos de Aragón y de Valencia y Principado de Cataluña, Madrid, 1896-1922, no alcanzó a publicar las de Aragón.

${ }^{44}$ J. Delgado Echeverría, Los Fueros de Aragón, Zaragoza, Caja de Ahorros de la Inmaculada, 1997, pág. $69 b$.

45 Texto en S. Romeu Alfaro, «Cortes de Monzón de 1362», AHDE, 1977, vol. 47, págs. 741796. Salvo inadvertencia mía, no indica la naturaleza de este documento ni su data, sólo su localización archivística. Volveré enseguida sobre esta edición. 
aceptado — según la editora- la petición real, en ellas ahora solicitada a los restantes territorios de la Corona).

De las mismas Cortes de 1362-1363 se han publicado unas actas mucho más extensas ${ }^{46}$. A diferencia del relato antes examinado, hasta la intervención de los obispos y el magistral se emplea el latín, no el catalán. En éste, por el contrario, responden brevemente los asistentes, que también lo utilizan en un acuerdo sobre el subsidio solicitado por el Rey. En la misma lengua está incluida la Proposición real ${ }^{47}$ : A nostre Senyor Deu ha plagut que nos som vostre rey... Tras continuar el documento en latín, este uso se interrumpe en sendas ocasiones para fijar el subsidio que otorgan sucesivamente Valencia, Aragón y Cataluña, con sus respectivas justificaciones, todas en catalán. A una nueva intervención, asimismo en catalán, del rey, los procuradores voce tumultuosa dixerunt et responderunt: «Plau-nos, senyor, plau-nos», et aliqui ex eis dicebant: $« o c, o c »$. Siguen nuevas y muy largas intervenciones de cada territorio confederado: las de Cataluña se manifiestan en catalán y cada una de las proposiciones aceptadas por el rey se remata con la fórmula Plau al senyor Rey; las intervenciones de Aragón, todas por partida doble, al actuar las villas con independencia de la nobleza y clero, en aragonés, con la fórmula Plaze al senyor Rey; las de Valencia en catalán, con algunos aragonesismos en sus comienzos, y, cuando procede, acompañadas de la fórmula Respon lo senyor Rey que li plau.

Finalmente se incluyen las Constitutiones Catalonie, totalmente en latín; siguen los Capitols generals del Regne de Valentia, en catalán, como también una Concordia, firmada por el Rey e incluida bastante antes de que, siempre en latín, se llegue al final de la exposición. Faltan los acuerdos para Aragón, hoy conocidos por la versión latina oficial y por otra en aragonés conservada en un manuscrito independiente ${ }^{48}$.

46 Actas de las Cortes generales de la Corona de Aragón de 1362-63, recop. y trans. de J. M. Pons Guri, Madrid, Ministerio de Cultura, 1982. En parte se atiene al mismo manuscrito citado en la nota precedente (a juzgar por la referencia archivística y la fundamental coincidencia textual, aunque parece no conocer su edición), completado con otros documentos. Faltan también datas.

47 El mismo discurso, con variantes, puede verse también en Parlaments a las Corts..., pág. 24-26. No se indica la fuente.

48 Una traducción aragonesa independiente (Fueros feytos en el lugar de Monçon...) figura en J. Bergua Camón, «Fueros de Aragón de 1265 a 1381», ADA, 1949-1950, vol. 5, págs. 455-575, publicación que completa la del mismo manuscrito realizada por J. L. Lacruz Berdejo, «Fueros de Aragón hasta 1265», ADA, 1945, vol. 2, págs. 223-361. Según este último autor, en una breve (y deficiente) introducción, dicho manuscrito está en letra aragonesa de principios del siglo XV. Comprende los libros I-X y, parcialmente, el XI de los Fueros de Aragón. 
19. A lo largo de los años 1371-1372 Pedro IV celebró Cortes particulares de Aragón en Caspe, Alcañiz y Zaragoza, reunión única ${ }^{49}$, con mudanzas de localización. Salvo parte del formulario llamamiento inicial; una carta de los procuradores de Ejea para recordar su condición de infanzones, acompañado de algunas reclamaciones anejas, pero ni siquiera una declaración similar de carácter protocolario formulada por los de Teruel, y una cuestión particular de orden personal, documentos todos éstos en latín, el completo trascurso de las sesiones queda consignado en aragonés. Siguiendo con la práctica antes referida, los acuerdos tomados en estas Cortes fueron traducidos de romanz en latin, según expreso mandato de Pedro IV al Justicia de Aragón, para al dezeno libro de los fueros aiustar et aiungir, según ya comenté.

También hubo reunión de Cortes particulares de Aragón el año 1375, en Tamarite $^{50}$. La adscripción lingüística de las actas corresponde al aragonés como en las anteriores. Del latín sólo se valen una carta del Justicia; otra, real, para cuestiones procedimentales; una cédula del conde de Urgel para reclamar sus derechos sobre Fraga; y una súplica de Tamarite y San Esteban sobre su vinculación a la Corona. De estas Cortes únicamente pasó un acuerdo general, de escaso relieve, a la compilación foral.

20. No he visto mencionado en la historiografía lingüística de Aragón que el dualismo idiomático de catalán y aragonés llegase a la disensión, hasta el punto de haberse producido conflictos en las altas instituciones de la Corona. Desconozco si en dicho nivel la desavenencia se produjo con anterioridad a este momento o, incluso, al reinado de Pedro IV, aunque todo hace conjeturar que sus raíces venían de tiempo atrás y que iba unida a antagonismos regionales de diverso orden, algunos de los cuales quedan más adelante expuestos. En cualquier caso, la disparidad lingüística se atestigua de modo expreso y se somete a discusión precisamente durante aquel reinado, conflicto repetido entre los posteriores. Las disensiones se suscitaron en unas accidentadas Cortes ${ }^{51}$ conjuntas de todos sus territorios, celebradas en Monzón, 1382-1383, tras numerosos aplazamientos (los aragoneses se negaban a participar en ellas) y des-

49 Cortes de Caspe y Alcañiz y Zaragoza, 1371-1372, ed. de M. L. Ledesma Rubio, Valencia, Anubar, 1975. Se utilizan dos manuscritos de finales del siglo XV.

${ }^{50}$ Actas del proceso de Cortes de Tamarite de 1375, ed. de M. L. Ledesma Rubio, Valencia, Anubar, 1979. Se utiliza un manuscrito de mediados del siglo XV. Sobre algunos documentos de estas Cortes, cf. M. R. Fort Cañellas, «Estudio lingüístico de sesenta documentos del Proceso de las Cortes de Tamarite de Litera del año 1375, según el manuscrito 2», AFA, 1977, vol. 20, págs. 141-262.

51 Cort general de Montsó, 1382-1383, ed. y est. de J. Baiges y otros, Barcelona, Generalitat, 1992. 
plazamientos (intencionados, unos; obligados, otros). Entre varios y serios motivos de discrepancia (tales, la adscripción de Fraga a Aragón o a Cataluña; la destitución de varios consejeros; etc.) que enfrentaban a las representaciones territoriales, surgió una violenta discusión sobre la lengua en que había de pronunciarse la Proposición real. Cada uno de los miembros de la confederación pretendía que correspondiese a la suya. Tras tensos debates, se alcanzó una solución de compromiso: el discurso del rey se pronunciaría en catalán; la contestación de los Brazos, en aragonés. Solución —así creo entenderla- favorable al catalán, puesto que éste se identifica como la lengua propia del poder real, con la notoriedad e influencia consiguientes. Repárese, sin embargo, en que tal resolución no supone, de por sí, ninguna novedad, pues de igual modo ya se había procedido en otras Cortes anteriores, como las de 1362-1363, veinte años antes, según he referido.

Las actas procedimentales, en su redacción latina, de las citadas Cortes de 1382-1383 acreditan, de acuerdo con el criterio idiomático establecido al comienzo de ellas, que el rey dijo la proposición in lingua seu ydiomate ut pretangitur cathalano, tras una oportuna (por las apremiantes circunstancias indicadas) cita bíblica, ligeramente adaptada: Ecce assum quia uocastis me ${ }^{52}$. La respuesta, in ydiomate aragonense, corrió a cargo de su hijo, el infante Martín (en 1396 ceñiría la corona aragonesa), quien comenzó así: Senyor, la Cort ha hoida la vuestra buena proposicion... Pedro IV no abandonó el catalán para sus varias intervenciones posteriores y a esta lengua se incorpora en lo sucesivo el infante, cambiando, por tanto, la de su primera intervención, salvo para declaraciones formularias, en cuya expresión siempre suele predominar el latín. En lengua catalana se manifiestan asimismo los procuradores; también, alguna vez, en latín. Con excepción -extensa excepción- de los capítulos particulares correspondientes a Cataluña, Valencia y Mallorca, los particulares de Aragón, como asimismo la aprobación real, están redactados en aragonés.

21. Sin olvidar la limitación del material disponible, los análisis anteriores dejan patente que las Cortes generales de la Corona se desenvolvieron mayoritariamente en catalán, con reserva, no siempre, de algún espacio para el aragonés en debates y materias que afectaban de modo específico a su ámbito territorial. Sólo en las Cortes particulares de él, la lengua aragonesa disponía de la exclusividad $^{53}$. Así y todo, su presencia oral en tales reuniones resulta, pues,

${ }^{52}$ El mismo discurso, con variantes, puede verse también en Parlaments a las Corts..., págs. 52-56. No se indica la fuente.

${ }^{53}$ Contrasta esta situación con la glosa que repiten los foristas aragoneses al Libro de los Fueros cuando afirman: Nota regnum Aragonie est caput principale dominacionis regis Aragonum. Otra glosa refiere que durante el reinado de Alfonso IV, suscitada una discusión entre ara- 
considerablemente más generalizada que su aplicación escrita en la documentación real ordinaria atingente a Aragón.

Aun sin explícita mención de materia lingüística, sobre ésta sin duda hubieron de repercutir, con mengua indirecta de la lengua catalana, algunos acuerdos de las Cortes aragonesas ${ }^{54}$, coincidentes en establecer ciertas limitaciones a la presencia de catalanes en torno al monarca y en los organismos de su curia.

Las Cortes de Zaragoza de 1364 establecen ${ }^{55}$ que el infante primogénito jurado por rey desde los 14 años tiene jurisdicción civil y criminal y que los cargos de canciller y vicecanciller debían recaer en aragoneses domiciliados en Aragón. Al cumplir 25 años puede escogerlos entre los de qualquiere nación que quiera.

Las Cortes de Zaragoza de 1380 prohíben ${ }^{56}$ que ningún uxier ni ningún asistent al senyor rey, catalán o strangero, aturase cerqua del senyor rey. Asimismo, que catalán alguno no podía ni devía aver officio alguno ni usar de aquel ni seyer en sus Cortes direttamente ni indiretta.

22. No parece verosímil que la tensión lingüística se redujese a ocasiones solemnes como las indicadas, aunque probablemente tampoco tenía oportunidad de manifestarse de modo habitual en la vida ordinaria ni, en todo caso, de afectar a la inmensa mayoría de los súbditos de la Corona. Ahora bien, la diversidad idiomática no había pasado inadvertida, estaba denunciada desde muchos decenios antes. Para el gerundense Ramon Muntaner (1265-1336), que escribía su Crònica en Valencia, entrado el siglo XIV, si ben catalans e aragoneses són d'un senyor, la llengua no és una, ans és molt departida. La disparidad no debía de ser muy de su agrado, pues produce la impresión de pretender justificarla con situaciones semejantes experimentadas por otras muchas renombradas regiones de Europa, en las cuales existía tal diversidad de lenguas com ha de catalans a aragoneses, comparación que también aplica a Castilla, al suponer

goneses, catalanes y valencianos sobre dónde debía coronarse el rey, fuit decisum quod in regno Aragonum quia est totius celsitudinis caput et in civitate Caesarauguste et non in alibi. Aunque reconoce que per disidiam, Aragonenses non habuerunt dicesionis cartam. Cf. A. Pérez Martín, «La primera codificación oficial de los Fueros aragoneses: las dos compilaciones de Vidal de Canellas», Glossae, 1990, vol. 2, págs. 9-80; pág. 65.

54 Cortes del Reino de Aragón, 1375-1451. Extractos y fragmentos de Procesos desaparecidos, ed. de A. Sesma Muñoz y E. Sarasa Sánchez, Valencia, Anubar, 1976. Se recogen en esta publicación los resúmenes conservados de procesos de Cortes cuyo contenido completo se ha perdido. Los textos, en cuanto a su literalidad, no poseen plena fiabilidad, por estar tomados de fuentes diversas, procedentes de copias tardías. Sí, por lo general, merece crédito el contenido de las noticias que trasmiten.

55 Cortes del Reino..., pág. 48.

56 Ibíd., pág. 81. 
en ella moltes províncies qui cascun parla son llenguatge, y a la existente entre Cataluña y Valencia.

23. La decidida opción de Pedro IV por el catalán, patente en su documentación referente a las tareas de gobierno, al igual que en sus cartas privadas, queda confirmada de modo rotundo por los textos legales y culturales en cuya composición o traducción asimismo intervino personalmente, bien disponiendo su realización, bien compartiendo autoría. En este sentido, apenas cabe aquí sino recordar la importancia de iniciativas tales como las Ordinacions y el ritual de la coronación, antes comentados, amén de otras traducciones que, muy de paso, mencionaré.

Voy a prestar, en cambio, una particular atención a algunos aspectos lingüísticos de su Crònica $^{57}$ por cuanto que esta obra ofrece nuevas perspectivas y ratifica otras, someramente apuntadas antes, sobre las actitudes idiomáticas de Pedro IV. Reproduzco un buen número de pasajes en estilo directo, cuyo plurilingüismo revela de modo inmediato el criterio seguido por el autor de la Crònica $^{58}$.

La reina Leonor se dirige en castellano a su esposo Alfonso IV de Aragón, quien la responde en catalán $(1020 b)$ :

E, oint aquestes paraules, lo senyor rei, nostre pare, dix a la reina:

-Ah, reina, açò volíets vós oir!

Et ella, tota irada, plorant, dix:

- Senyor, esto non consentria el rei don Alfonso de Castella, hermano nuestro, que ell no los degollase todos.

E lo senyor rei respòs:

- Reina, reina, el nostre poble és franc...

El rey Pedro I de Castilla dispone que un portero dé muerte a la recién citada Leonor. El ejecutor de la orden se lo comunica a la sentenciada en la lengua común a ambos $(1124 b)$ :

-El rey mi senyor vos manda matar.

La Crònica inserta una larga carta, Sevilla, 1356, que debo acortar considerablemente, de Alfonso XI a Pedro IV. Su texto es indudablemente castellano,

57 Estimo oportuno recordar aquí la existencia de numerosos problemas textuales, no resueltos, que ofrece la composición de esta obra, iniciada en torno a 1375, cuya redacción definitiva se sitúa entre 1382 y 1383 . Baste la precedente indicación, más el solo dato de que con el rey colaboraron varios redactores; entre los más destacados, Mateu Adrià, Bernat Descoll, Tomàs de Canyelles y Arnau de Torrelle.

58 Como finalidad secundaria, pretendo con ellos ofrecer unas muestras literales de las lenguas empleadas, aunque no procedan de una edición crítica (inexistente). 
aunque se observan algunos rasgos gráficos, inevitables, fónicos y gramaticales que corresponden mejor al aragonés. Dice así (1126a):

Rey

Fazemos vos a saber que viemos vuestra carta que nos embiastes sobre razón de una nao que vos querelló Ramón de Frexnete, mercadero de la cibdat de Mallorques, que diz que'l fue tomada con fierro [...]. Nos rogávades que fesíssemos entregar las ditxas cosas que'l fueron tomadas e robadas o las quantías [...] con el interesse e despeses [...] en manera que el ditxo Ramón de Frexnet hoviese entegra de todo esto [...]. Somos maraveyado de vos embiarnos dizir tales palavras [...]. De lo qual rezebiemos de vos fasta aquí todo los contrario en mutxas cosas que son estadas [...]. Desapoderastes de los ditos maestres e de su juridicción, non lo podiendo vos fazer de dretxo [...], faziéndonos guerra así com nos la farían enemigos [...]. Lo que no podieron llevar, etchárenlo en la mar, vidiéndolo nos per nuestros ojos [...]. Estas cosas e desaguisades nos fueron fetxas de vos.

A la cual responde Pedro IV con otra, Perpiñán, 1356, de mayor extensión aún, en aragonés, es decir, abandonando también en este caso la lengua marco de la Crònica, su preferida, el catalán, con alguna huella de éste (1128a):

Rey:

Vuestra letra havemos recebida hoy [...]. Si aquesto no queríades fer render, havríamos a fer al dito mercadero lo que de justicia e de razón éramos tenidos de fer [...]. La dita nuestra carta salié de nuestra cancellería por la forma e manera que se acostumbrave de requerir en tal razón por justicia un rey a otro. E los reyes aquello que sale por justicia de lur cort no han acostumbrado de veer, e nos tan pocho no sabiemos nada d'esta carta, mas sómonos certificados, después que la dita carta havemos recevida, que el rey vuestro padre, e los otros reyes escrivíen a nos e nos a ellos diús la forma de suso dita. Pero esnos sido dito por Mateo Adrián, nuestro escrivano mayor, tenient los nuestros siellos, que [...] fue convenida cierta forma [...] de escribir [...] de semblantes aferes de nos a vos e de vos a nos. E el dito Mateo Adrián dize que en la dita nuestra carta no fue seguida la dita forma [...], porque el escrivano qui fize la dita carta, no sabiendo la dita forma, fizo aquella en que es acostumbrado de escribir en tal caso a los otros reyes. E fue errada el dito escrivano [...]. Entro agora nos teníades por amigo e que havíamos recebidas del rey, vuestro padre muytas de buenas obras [...]. Es cierto que le fezimos en sus aferes grandes ajudas e buenas obras. E a aquesto non queremos más dizir, porque nenguno no s'en debe loar en su feyto [...]. Los frayres de Calatrava qui son en Alquanyiç, en la nuestra senyoría, dizen que, según lur Orden, esleyeron e fizieron maestre don Johan Ferrández [...]. E no es razón que vos agreugedes por esto [...]. Si nos lo feciéssedes saber, havriamos hi dado aquell escarmiento que ferse devía entre reyes que eren amigos [...]. Es feyta mención de las paces que eren entre nos e vos [...] por buena amor. 
Alfonso XI la contesta, pocos días después, en castellano, con algunas peculiares grafías $(1129 b)$ :

Haviendo fetxo los males e danyos [...], vuestras gentes de Mallorcas tomaron [...] las ditxas naves [...]. Si vos quisiéredes embiar a nos cavallero, bien lo podiéredes embiar seguro, car los mensatgeros de los reyes seguros deven seer.

Dos meses después, desde Calatayud, sigue la correspondencia, mediante otra extensísima carta de Pedro IV, en aragonés, con análogas características a las apuntadas para su anterior $(1130 b)$ :

Sí lo havemos feyto regonocer agora con de cabo. Pero, si vos nos queredes declarar qué es aquello a que no us fiziemos respuesta, ferla y hemos [...] Se ende iva antes que el pleyto fués desembargado e terminado. E aun fazía peyor, porque se ende llevaba los ditos mercaderos, porque lo requería que los li rendesse. E el dit patrón e los otros qui eren en la dita nau, tiraronle con sayetas e fuese ende con a dita nau [...]. Requerilo que li rendés los ditos mercaderos, e non lo quiso fer. E sobre esto peleyaron [...]. El judez de Mallorcas confiscó al fisco nuestro la dita nau [...]. Todo esto se fazía, present el dito mandadero vuestro, concordant con el dito nuestro Consello [...]. Del qual feyto, rey, en la dita vuestra carta no os embiastes dizir alguna cosa por que non vos hi podíamos responder [...]. Los reyes que han buenas pazes e firmas treguas non deven fer mal l'uno al oro sin requirimiento, porque por aquello se veyen las cosas si son seydas feytas con dereyto o no.

Se reproducen, datadas en 1364, estas frases, mixtas de aragonés y castellano, puestas en boca del conde de Trastámara, el futuro Enrique II de Castilla, en conversación con Pedro IV (1146b):

- Senyor, con tales jornadas crebanten los grandes reyes los ojos a los otros reyes, lures enemigos. Er, en esta jornada, senyor, havets crebantado al rey don Pedro de Castiella l'ojo dretxo, e vos sots mostrado rey e senyor por mantener e defender vuestro regno. E assí, senyor, agora es tiempo de folgar e dar vos plazer, pues havets alcançada la honra que a vos se pertanesce.

El mismo año, Pedro I de Castilla sostiene la siguiente conversación con sus consejeros, bien entendido que he debido reducir al mínimo suficiente, para comprender las alternativas del diálogo, todas las amplias acotaciones al diálogo, naturalmente en catalán, aquí traducidas por mí. En este dilatado pasaje, básicamente castellano, el redactor del texto introduce muchos y muy marcados rasgos catalanes, incurriendo en una caótica heterogeneidad idiomática hasta llegar a la incoherencia (1148b):

-Yo us he fetxos aquí ayuntar por aver consiello de vosotros. Qué vos parece de haver pelea con el rey d'Aragón, qui, assín como sabedes, es cerca de 
nosotros e havemos por cierto que huy será en las partides de Oriola con su poder?

El maestre de Santiago responde:

-Senyor, grant tiempo ha que Dios ha fetcho departimiento entre la Casa de Castiella e la Casa d'Aragón, assín que, si del regno de Castiella se facíen cuatro partes e dave la una parte d'ellas, daría mayor tierra que no tiene al rey d'Aragón e aun s'hi fincaría grande rey [...]. Esti día vos vençredes el dito rey d'Aragón e [...] aprés, emperador d'Espanya.

Oídos varios consejeros, el rey preguntó:

- Hay aquí alguno rapaç que tenga un pa?

Tras haberlo recibido, continuó su discurso:

- Porque sepades yo en qué os tiengo, es assín, que con esti pan que tienlo en la mano, pienso que fartaría quantos leyales haya en Castella.

Volvió preguntar:

—Qué consellades?

Y le fue respondido:

- Senyor, consellamosvos que en todas guisas del mundo que cras de manyana vós anés a combatre con el d'Aragón.

Replicó el rey:

- Ha, qué bon consejo! Con este pedaço de pan en la má hartaría todos cuantos leales ha en Castiella.

24. Como se habrá observado, Pedro IV pone en boca de cada personaje la lengua que le es propia, separándose de la lengua básica del texto, aunque desde ésta se produzcan inevitables contaminaciones, cuya motivación no puede ser necesariamente atribuida al rey, por las antes mencionadas anomalías sufridas en la transmisión de la obra. Queda bien de manifiesto el criterio historiográfico de Pedro IV, que se corresponde perfectamente con su preocupación por la exactitud documental, según quedó apuntado al comienzo del presente estudio. Apenas merece destacarse que, coherente con el citado criterio, sus cartas, sobre cuya autenticidad histórica no cabe dudar, dirigidas a Alfonso XI insertas en la Crònica presentan redacción aragonesa. Era el modo de dirigirse Pedro IV a los reyes castellanos, según quedó antes de manifiesto al analizar las colecciones documentales. 
25. Entiendo como otra manifestación del esmero dispensado por Pedro IV a toda manifestación escrita el hecho de que con frecuencia designe por su nombre específico a las lenguas vulgares, bien consciente de su diversidad. He aquí unas muestras ${ }^{59}$ :

Istorias en frances [...] fazemos [...] transladar en aragones (1370).- Havemos feyto translatar de frances en aragones (1371). - Havemos fecho translatar en aragones [...] de las Istorias en frances (1372).

Biblia que es escrita en vulgar cathalá (1351)._Lançalot qui es scrit en lengua catalana (1362). - Lançalot [...] scrit en cathala (1362).

Libres en lenguatge castella [...] fes tresladar en nostre lenguatge (1365).

Libri [...] in lingua gallicana scripti (1343)._Libre [...] en lengua françesa scrit (1343).- Trayades [...] las Istorias en ffrances (1370).

Sin que falte una mención genérica:

Biblia vestra in romancio scripta (1339).

26. De las anteriores indicaciones, una supera el interés que, inicialmente, les había otorgado. Es la contenida en carta, 1365, escrita en catalán, por Pedro IV a su esposa para referirse a la traducción de las Partidas alfonsinas a nostre lenguatge (cf. § 7). Independientemente de que el posesivo nostre encierre valor mayestático, la atribución indicada deja patente cuál es la lengua que el rey considera como la suya propia. Bien puede, pues, tomarse como una apreciable confirmación de los resultados conseguidos en los varios análisis que he venido efectuando.

59 Proceden todas de Rubió y Lluch, Documents... Consigno tras cada una la data del documento correspondiente. 